\title{
DESIGN AND DEVELOPMENT OF 72.83 MHZ SIGNAL BOOSTER TRANSMITTER TO INCREASE THE REMOTE CONTROL COVERAGE
}

\author{
Catur Budi Waluyo ${ }^{1}$ Arina Rizqiyah ${ }^{2}$, Denny Dermawan ${ }^{3}$ \\ Program Studi Teknik Elektro \\ Sekolah Tinggi Teknologi Adisutjipto \\ Jl. Janti Blok R Lanud Adisutjipto Yogyakarta \\ catur_budiwaluyo@yahoo.co.uk
}

\begin{abstract}
In the development of wireless communication, controlling an unmanned aircraft over long distances is a challenge. One technique to make it happen is by using a signal booster that can increase the range of the Unmanned Aerial Vehicle controller. So that the range in controlling Unmanned Aerial Vehicle using Remote Control (RC) can be further away.

The Signal booster operated at $72.83 \mathrm{MHz}$ frequency was designed with four levels of amplifier with 2SC930, 2SC2053 and 2SC1971 series transistors. This signal booster was designed to be operated in class A for level I, II, III, and class C for level IV with the matching impedance circuit namely type $T$ and $L$. In the transmitter, the antenna was used omnidirectionally. The test method was carried out by means of power measurement and VSWR (Voltage Standing Wave Ratio).

Based on the design of the frequency used $72.83 \mathrm{MHz}$ with a bandwidth of $30 \mathrm{kHz}$. The amplitude peak level was $-27 \mathrm{dBm}$ with a reference level of $0 \mathrm{dBm}$. The measurement results show the signal booster can work at a frequency of $72.83 \mathrm{MHz}$ with an output power of 4.5 watts or a gain of $16.58 \mathrm{~dB}$ and approaching the designer's results. The measured Voltage Standing Wave Ratio (VSWR) which measures 1.1 with a minimum VSWR limit of 1. So that based on these measurements the signal booster results are successfully designed and produce a very small reflection factor coefficient of 0.09 and 0.048 .
\end{abstract}

Keywords: Signal Booster, Amplifier, Remote Control

Abstrak

Pada perkembangan komunikasi wireless, pengendalian suatu pesawat tanpa awak dengan jarak yang jauh merupakan sebuah tantangan. Salah satu teknik untuk mewujudkannya yaitu dengan menggunakan penguat sinyal (signal booster) yang dapat menambah jangkauan pengendali pesawat tersebut. Sehingga jangkauan dalam pengendalian pesawat tanpa awak menggunakan Remote Control (RC) dapat semakin jauh.

Signal booster yang dioperasikan pada frekuensi $72,83 \mathrm{MHz}$ ini dirancang dengan empat tingkat penguat dengan transistor seri 2SC930, 2SC2053 dan 2SC1971. Signal booster ini dirancang dioperasikan pada kelas A untuk tingkat I, II, III, dan kelas C untuk tingkat IV dengan rangkaian penyesuai impedansi yang digunakan yaitu tipe $\mathrm{T}$ dan L. Pada bagian transmiter, antenna yang digunakan omnidirectional. Metode pengujian dilakukan dengan cara pengukuran daya dan VSWR (Voltage Standing Wave Ratio).

Berdasarkan perancangan frekuensi yang digunakan $72.83 \mathrm{MHz}$ dengan bandwidth $30 \mathrm{kHz}$. Level puncak amplitudo yang dihasilkan sebesar $-27 \mathrm{dBm}$ dengan dengan reference level $0 \mathrm{dBm}$. Hasil pengukuran menunjukkan penguat dapat bekerja pada frekuensi 72,83 $\mathrm{MHz}$ dengan daya keluaran 4,5 watt atau gain sebesar 16,58 dB dan mendekati hasil perancangan. Voltage Standing Wave Ratio (VSWR) yang diukur sebesar 1.1 dengan batas minimal VSWR yaitu 1. Sehingga berdasarkan pengukuran tersebut maka hasil signal 
booster yang dirancang berhasil dan menghasilkan koefisien faktor pantul yang sangat kecil sebesar 0.09 dan 0.048 .

Kata kunci: Signal booster, Penguat, Remote Control

\section{Pendahuluan}

Pada perkembangan teknologi kedirgantaraan, sekarang banyak pesawat tanpa awak yang digunakan dalam berbagai aplikasi kehidupan sehari-hari, baik dalam foto udara sampai pengiriman paket dalam e-commerce. Pesawat awak ini juga disebut dengan Unmanned Aerial Vehicle (UAV) yang juga digunakan dalam bidang telekomunikasi untuk membawa sistem komunikasi 4G LTE (Waluyo, 2016; Waluyo \& Iskandar, 2015). Sistem pengendalian UAV bisa secara manual maupun dengan otomatis. Pengendalian manual dengan cara menggunakan Remote Control (RC) sebagai pengendali utama.

Pada Penelitian ini untuk pengendalian pesawat UAV dengan cara manual. Sehingga pesawat dikendalikan hanya dengan menggunakan RC. Menurut (Waluyo, 2014) jangkauan komunikasi tanpa kabel juga dipengaruhi oleh frekuensi yang digunakan, semakin kecil frekuensi yang digunakan maka jarak jangkauan juga semakin dekat. Pada penelitian ini frekuensi yang digunakan yaitu $72.83 \mathrm{MHz}$. Dengan frekuensi yang digunakan maka jarak jangkauan hanya mencapai 34.58 meter. Selain frekuensi yang digunakan menurut (Waluyo, 2014), untuk meningkatkan jarak jangkauan sistem komunikasi tersebut yaitu dengan menambah daya pancar.

Untuk memaksimalkan penerbangan pesawat UAV maka untuk meminimalisasi terjadinya Loss Contact maka pada penelitian ini membuat suatu perangkat yang digunakan untuk meningkatkan daya pancar tanpa mengubah frekuensi yang digunakan.

\section{Metode Penelitian}

2.1 Blok diagram sistem signal booster

Pada penguat sinyal (signal booster) pada penelitian ini terdiri dari beberapa blok diagram seperti pada Gambar 1.

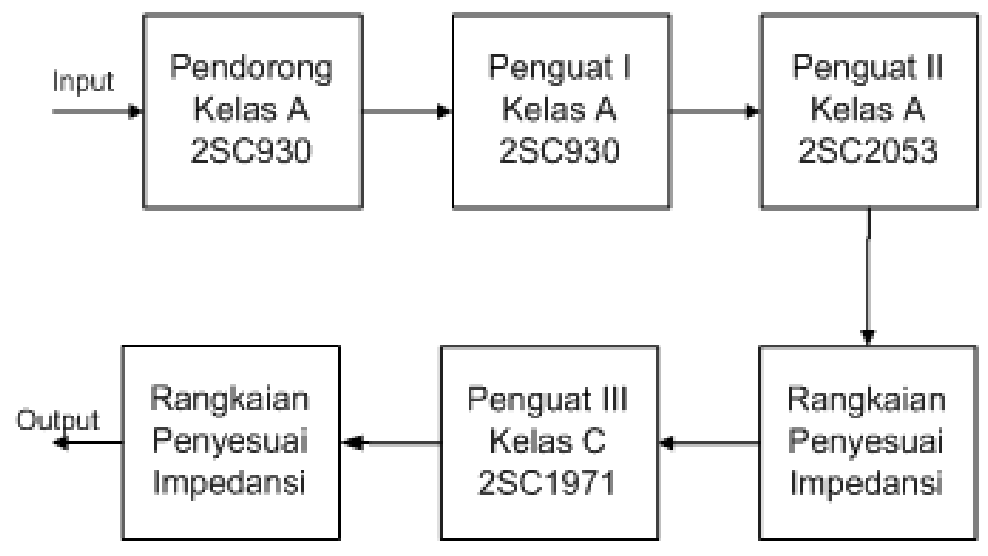

Gambar 1. Blok diagram signal booster

Berdasarkan Gambar 1 dapat dilihat bahwa sinyal masukan di proses dengan menggunakan transistor 2SC930 pada blok pendorong dan penguat 1 kelas A, kemudian masuk ke transistor 2SC2053 penguat II kelas A dengan daya 1 watt dan melalui rangkaian penyesuai impedansi agar sinyal yang di kirimkan terjadi transfer daya maksimum setelah itu sinyal di proses oleh blok diagram penguat III kelas $\mathrm{C}$ dengan komponen yang digunakan transistor 2SC1971 setelah itu masuk blok diagram rangkaian penyesuai impedansi dengan keluaran daya maksimum 6 Watt dengan pengoperasian frekuensi cutoff $175 \mathrm{MHz}$. 
2.2 Skema pengukuran dengan menggunakan signal booster

Untuk membandingkan hasil pengujian daya dan Voltage Standing Wave Ratio (VSWR) antara yang menggunakan signal booster dan tanpa menggunakan signal booster dapat dilihat pada skema Gambar 2. Pengukuran dilakukan pada kondisi tidak line of sight dan lokasi pengujian merupakan padat penduduk.

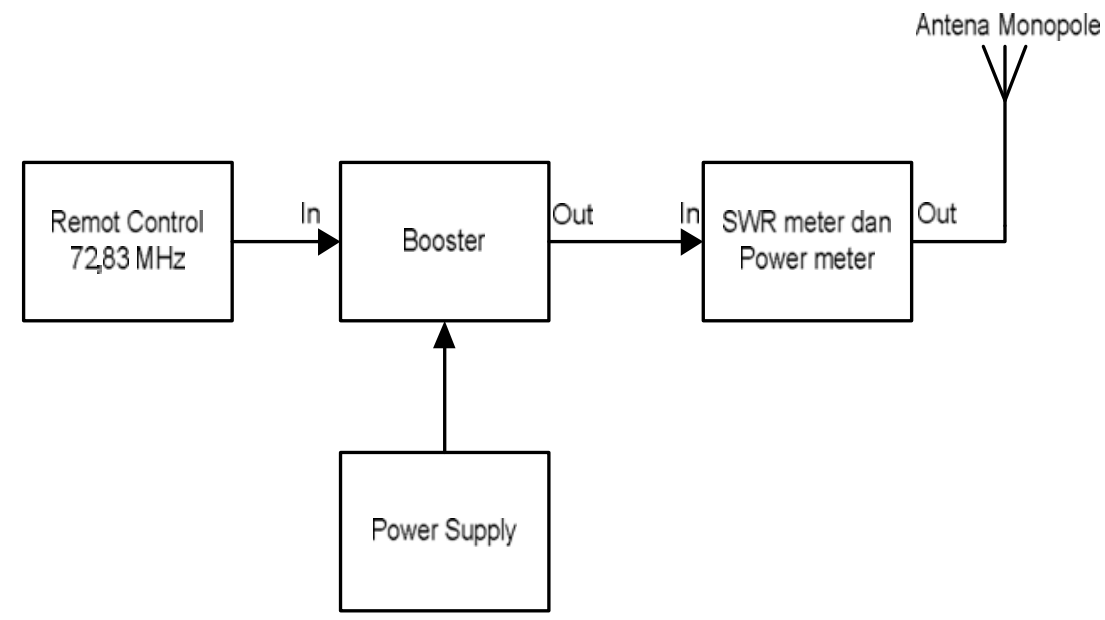

Gambar 2. Skema pengujian daya keluaran dan VSWR dengan menggunakan signal booster.

Perhitungan penguatan pada rangkaian ini dengan menggunakan Persamaan 1.

$$
\text { Gain }_{d B}=10 \log \frac{P_{\text {out }}}{P_{\text {in }}}
$$

Spesifikasi dari perancangan pada penelitian ini, dapat dilihat pada Tabel 1.

Tabel 1. Spesifikasi perancangan dari signal booster

\begin{tabular}{|l|l|}
\hline Spesifikasi & Nilai \\
\hline Daya Keluaran (watt) & 5 \\
\hline VSWR & $1 \leq$ VSWR $\leq 1,5$ \\
\hline Gain (dB) & 17 \\
\hline
\end{tabular}

\subsection{Skema rangkaian Buffer}

Rangkaian buffer merupakan rangkaian penguat awal atau penguat tingkat satu. Pada rangkaian buffer ini digunakan komponen aktif transistor 2SC930. Namun untuk mendorong daya masukan bagi transistor seri 2SC930 ini ditambahkan sebuah rangkaian pendorong dengan menggunakan transistor seri 2SC903 (Tahap dkk, 2013; Putra,2012; wedlock,1969), hal ini dikarenkan daya keluaran dari remote control yang sangat kecil yaitu kurang lebih $100 \mathrm{~mW}$. Gambar 3 merupakan rangkaian buffer yang digunakan dalam perancangan signal booster ini. 


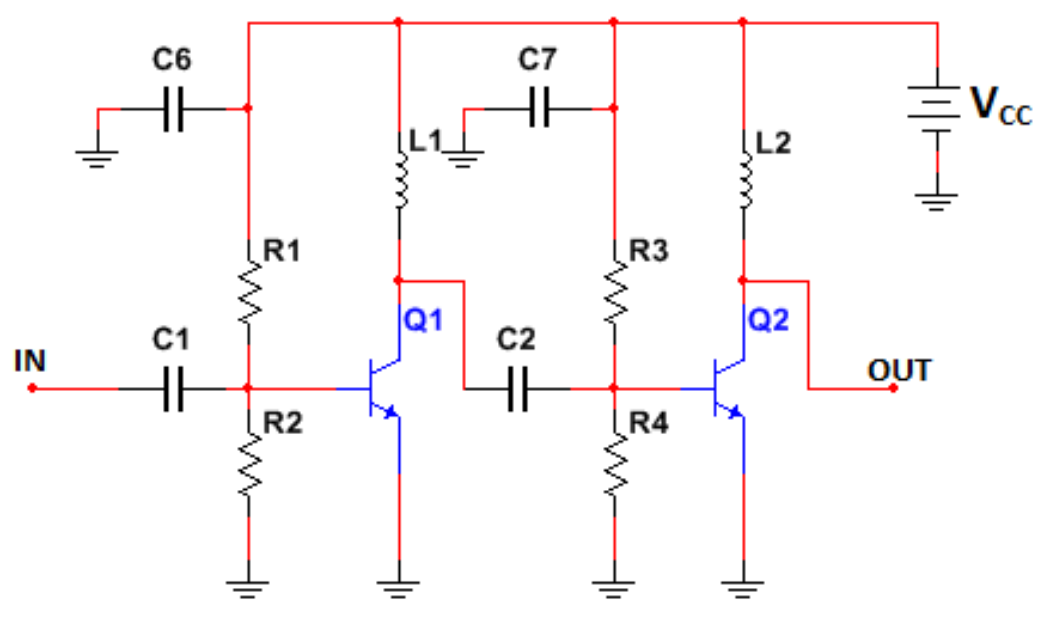

Gambar 3 Rangkaian Pendorong dan Buffer (Nugroho,2002;

Handayane,2012;Herdiana,2012)

\subsection{Skema rangkaian Driver}

Rangkaian driver menggunakan transistor dengan seri 2SC2053. Rangkaian driver pada penelitian ini menggunakan penguat kelas A dengan konfigurasi common emitter. Komponen pada rangkaian driver hampir sama seperti rangkaian pendorong dan buffer yaitu terdiri dari rangkaian bias pembagi tegangan. $\mathrm{R}_{5}$ dan $\mathrm{R}_{6}$ merupakan bias pembagi

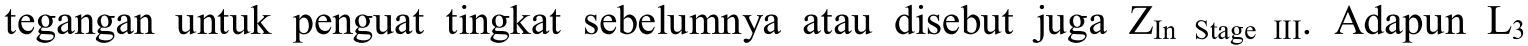
merupakan hambatan kolektor $\left(\mathrm{R}_{\mathrm{C}}\right)$ dari penguat tingkat driver atau disebut juga $\mathrm{Z}_{\mathrm{Out}}$. Untuk rangkaian driver dapat dilihat pada gambar 4.

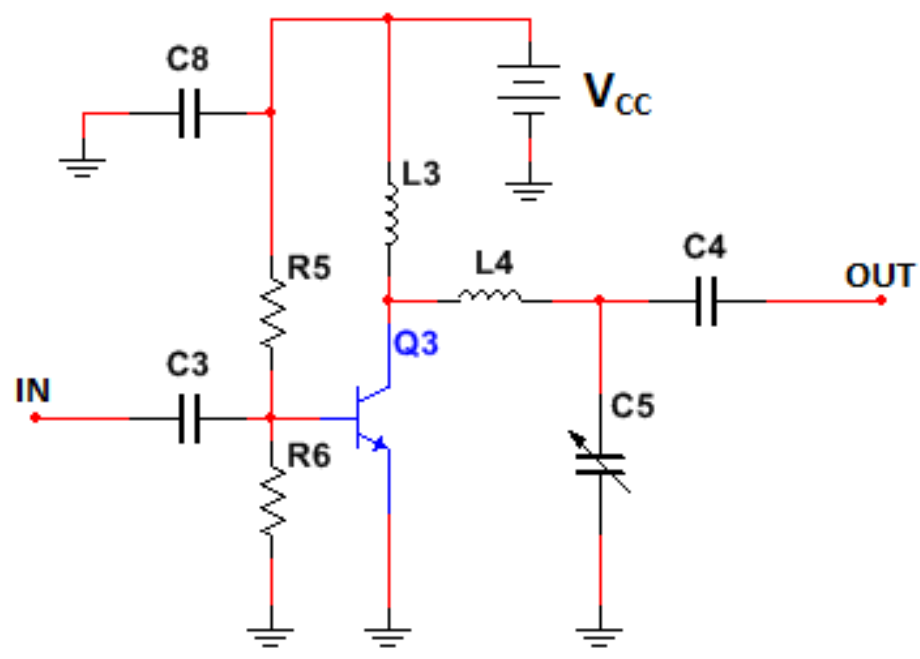

Gambar 4 Rangkaian driver (Utomo, 2012)

\subsection{Skema Rangkaian Final Amplifier}

Pada rangkaian final amplifier menggunakan penguat kelas C. Skematik dari rangkaian final amplifier mempunyai kesamaan dengan rangkaian driver yaitu terdiri dari RFC (RF Choke) yang berfungsi sebagai masukan biasanya disebut hambatan sumber $\left(\mathrm{Z}_{\text {In }}\right)$ dan juga dan induktor sebagai hambatan kolektor ataupun sebagai keluaran $\left(Z_{\text {Out }}\right)$. RFC (Choke) tersusun dari resistor yang diparalelkan dengan lilitan. Pada akhir rangkaian ini juga terdapat rangkaian penyesuai impedansi guna menyesuaikan impedansi keluaran dari rangkaian final amplifier dengan beban. Rangkaian penyesuai impedansi pada final 
amplifier ini juga menggunakan komponen $\mathrm{L}$ dan $\mathrm{C}$ serta menggunakan konfigurasi tipe $\mathrm{L}$. Untuk rangkaian Final dapat dilihat pada Gambar 5.

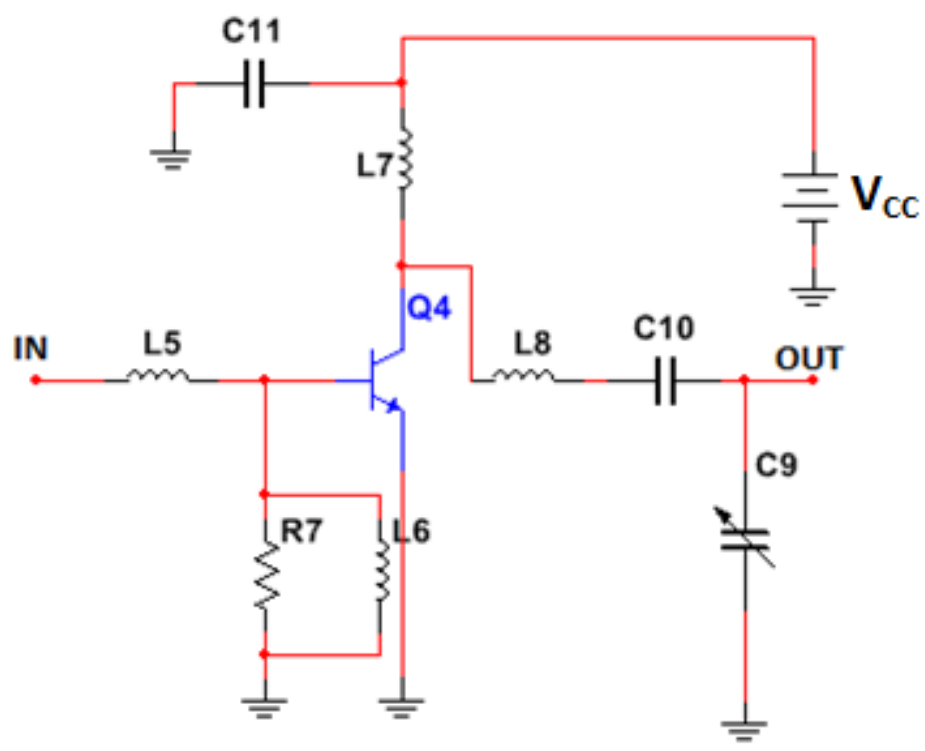

Gambar 5. Rangkaian final

\subsection{Pengukuran daya dan VSWR}

Pada tahap ini dilakukan pengukuran daya yang dipancarkan oleh remote control dengan menggunakan power meter. Selain itu juga dilakukan pengukuran menggunakan spectrum analyzer untuk mengetahui besarnya daya keluaran secara lebih jelas dan spektrum sinyal guna mengetahui kemungkinan terjadinya interferensi sinyal radio dengan frekuensi kerja yang digunakan. Sedangkan untuk mengetahui nilai Voltage Standing Wave Ratio (VSWR) dengan VSWR meter.

\section{Hasil dan Pembahasan}

\subsection{Skema Rangkaian signal booster}

Perancangan dari perangkat signal booster terdiri dari perancangan bias transistor sebagai pendorong, Buffer, Driver, Penyesuai Impedansi dan perancangan penguat final. Untuk setiap rangkaian tersebut dikombinasikan menjadi rangkaian penguat sinyal atau signal booster seperti pada Gambar 6. 


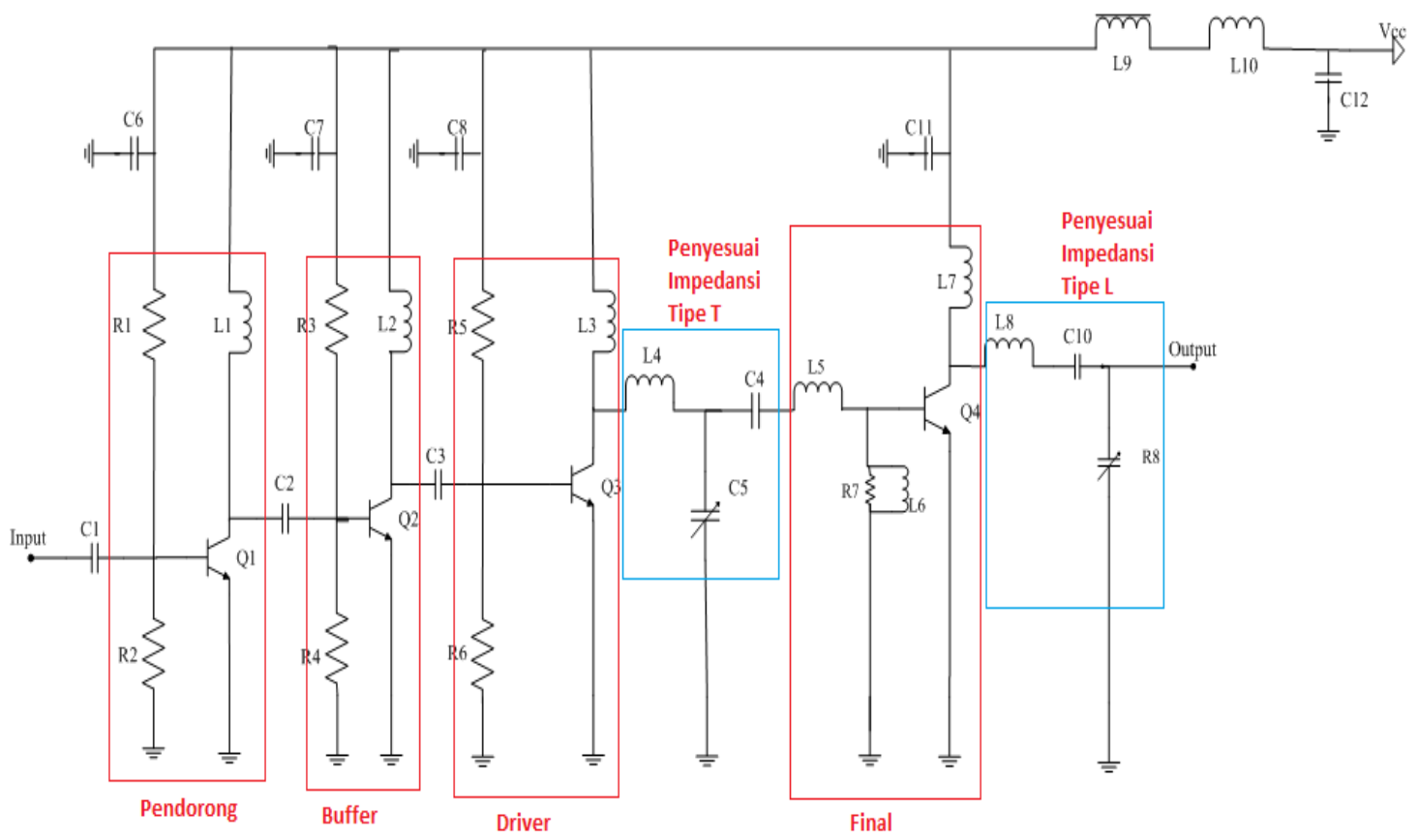

Gambar 6. Skema rangkaian signal booster

Berdasarkan skema rangkaian pada gambar 1 nilai toleransi masing-masing setiap komponen dapat dilihat pada Tabel 2. Setelah pembuatan skematik rangkaian langkah selanjutnya yaitu pembuatan Printed Circuit Board (PCB) rangkaian, untuk hasil pembuatan PCB dapat dilihat pada Gambar 7. Untuk hasil akhir penyolderan dan proses cetak PCB dapat dilihat pada Gambar 8.

Tabel 2. Notasi dan nilai komponen yang digunakan

\begin{tabular}{|l|l|l|l|}
\hline No & Notasi & Tipe & Keterangan \\
\hline 1 & $\mathrm{R}_{1}$ & Resistor & $68 \mathrm{k} \Omega$ \\
\hline 2 & $\mathrm{R}_{2}, \mathrm{R}_{4}, \mathrm{R}_{6}$ & Resistor & $10 \mathrm{~K} \Omega$ \\
\hline 3 & $\mathrm{R}_{3}$ & Resistor & $47 \mathrm{~K} \Omega$ \\
\hline 4 & $\mathrm{R}_{5}$ & Resistor & $33 \mathrm{~K} \Omega$ \\
\hline 5 & $\mathrm{~L}_{1}, \mathrm{~L}_{2}, \mathrm{~L}_{7}, \mathrm{~L}_{10}$ & Induktor & 5 lilit email $1 \mathrm{~mm}$ diameter $5 \mathrm{~mm}$ \\
\hline 6 & $\mathrm{~L}_{3}$ & Induktor & 6 lilit email $1 \mathrm{~mm}$ diameter $5 \mathrm{~mm}$ \\
\hline 7 & $\mathrm{~L}_{4}, \mathrm{~L}_{5}$ & Induktor & 2 lilit email $1 \mathrm{~mm}$ diameter $6 \mathrm{~mm}$ \\
\hline 8 & $\mathrm{~L}_{7}$ & Induktor & 5 lilit email $1 \mathrm{~mm}$ diameter $6 \mathrm{~mm}$ \\
\hline 9 & $\mathrm{~L}_{8}$ & Induktor & 3 lilit email 1 mm diameter $6 \mathrm{~mm}$ \\
\hline 10 & $\mathrm{~L}_{9}$ & Induktor & Toroida 10 lilit email 1 mm \\
\hline 11 & $\mathrm{Q}_{1}, \mathrm{Q}_{2}$ & Transistor & $2 \mathrm{SC} 930$ \\
\hline 12 & $\mathrm{Q}_{3}$ & Transistor & $2 \mathrm{SC} 2053$ \\
\hline 13 & $\mathrm{Q}_{4}$ & Transistor & $2 \mathrm{SC} 1971$ \\
\hline 14 & $\mathrm{RFC}_{2}\left(\mathrm{R}_{7}\right.$ dan $\left.\mathrm{L}_{6}\right)$ & - & resistor $470 \Omega$ dililit email $0,3 \mathrm{~mm}$ \\
\hline 15 & $\mathrm{C}_{1}, \mathrm{C}_{2}, \mathrm{C}_{3}, \mathrm{C}_{4}, \mathrm{C}_{10}$ & Kapasitor & $22 \mathrm{pF}$ \\
\hline 16 & $\mathrm{C}_{6}, \mathrm{C}_{7}, \mathrm{C}_{8}, \mathrm{C}_{11}, \mathrm{C}_{12}$ & Kapasitor & $100 \mathrm{nF}$ \\
\hline 17 & Trimmer $_{1}\left(\mathrm{C}_{5}\right)$ & Kapasitor & $\mathrm{s} / \mathrm{d} 47 \mathrm{pF}$ \\
\hline 18 & Trimmer $_{2}\left(\mathrm{C}_{9}\right)$ & Kapasitor & $\mathrm{s} / \mathrm{d} 30 \mathrm{pF}$ \\
\hline & \multicolumn{2}{|l}{} \\
\hline
\end{tabular}




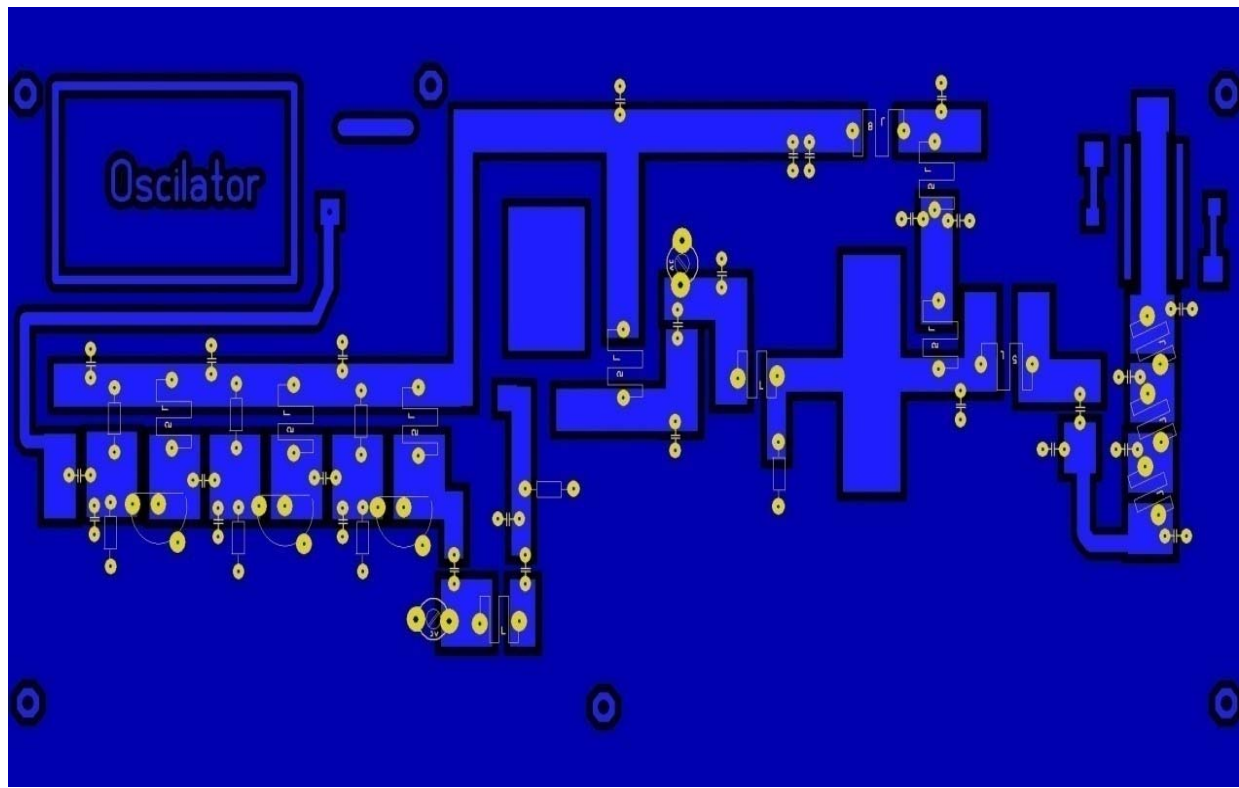

Gambar 7. Rancangan Printed Circuit Board (PCB) dari rangkaian signal booster

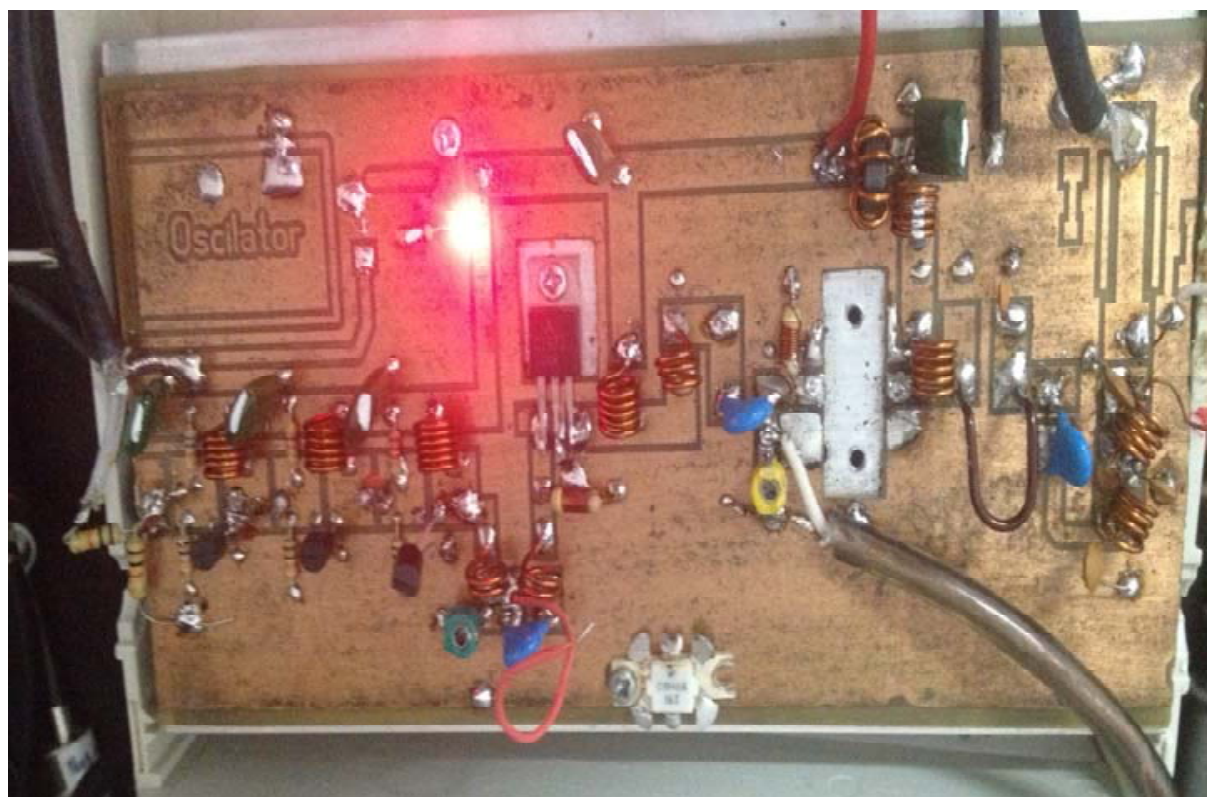

Gambar 8. Hasil Penyolderan dan susunan komponen dari signal booster

\subsection{Hasil Pengukuran daya dan VSWR}

Berdasarkan hasil pengukuran daya dan nilai VSWR sesuai dengan diagram pengukuran pada Gambar 2 maka di hasilkan data pengujian yang disajikan pada Tabel 3. Berdasarkan hasil pengujian daya keluaran menggunakan power meter pada Tabel 3 dapat diketahui bahwa perancangan signal booster menghasilkan daya keluaran akhir maksimum 4,5 Watt pada tegangan pencatu $13,8 \mathrm{~V}$ dan dengan perhitungan pada Persamaan 1 menghasilkan penguatan sebesar $16.53 \mathrm{~dB}$.

Tabel 3 Tabel Pengujian Daya dan VSWR pada Remote Control dengan Signal Booster

\begin{tabular}{|c|c|c|c|c|}
\hline Tingkat & $\begin{array}{c}\text { Catu Tegangan } \\
(\text { Volt })\end{array}$ & $\begin{array}{c}\text { Daya Masukan } \\
(\text { Watt })\end{array}$ & $\begin{array}{c}\text { Daya Keluaran } \\
(\text { Watt })\end{array}$ & VSWR \\
\hline Driver & 13,8 & 0,1 & 0,5 & 1,2 \\
\hline Final & 13,8 & 0,1 & 4,5 & 1,1 \\
\hline
\end{tabular}


Berdasarkan pengukuran dengan menggunakan Spektrum Analyzer dapat diketahui bahwa sinyal yang dipancarkan mempunyai bandwidth sebesar $30 \mathrm{kHz}$ yaitu dari 72,8 MHz sampai dengan $72,83 \mathrm{MHz}$. Selain itu juga dapat dilihat bahwa spektrum yang dihasilkan dari signal booster memiliki amplitudo puncak $-27 \mathrm{dBm}$ dengan reference level $0 \mathrm{dBm}$. Sedangkan spektrum derau yang dihasilkan dengan amplitudo $-40 \mathrm{dBm}$ dengan reference level $0 \mathrm{dBm}$. Sehingga berdasarkan pengukuran level spektrum sinyal yang dihasilkan signal booster masih di atas ambang dari level derau yang dihasilkan. Berdasarkan nilai VSWR pada Tabel 3 tersebut maka nilai koefisien faktor pantul sebesar 0.09 dan 0.048 .

\section{Kesimpulan}

Pada perancangan penguat sinyal pada penelitian ini dengan frekuensi yang digunakan $72.83 \mathrm{MHz}$, penguatan yang di hasilkan $16.52 \mathrm{~dB}$ dengan daya keluaran 4.5 watt. Sinyal yang dipancarkan mempunyai bandwidth $30 \mathrm{kHz}$ dengan level puncak amplitudo yang dihasilkan sebesar $-27 \mathrm{dBm}$ dengan reference level $0 \mathrm{dBm}$. Voltage Standing Wave Ratio (VSWR) yang diukur sebesar 1.1 dengan batas minimal VSWR yaitu 1.

\section{Daftar Pustaka}

Handayane, 2012, Realisasi Penguat Daya RF 5 Watt Untuk Pemancar Televisi Pada Band Frekuensi 174-181 MHz, Tugas Akhir, Teknik Elektro, Politeknik Negeri Banding, Bandung.

Herdiana, 2012, Desain dan Realisasi Driver Penguat Daya Pada Pengirim MS GSM (Frekuensi 890-915 MHz), Tugas Akhir, Teknik Elektro, Politeknik Negeri Bandung, Bandung.

Nugroho, Sapto, 2012, Rancang Bangun Penguat RF, Skripsi, Teknik Elektro, Universitas Diponegoro, Semarang.

Putra, T. H, Hendrantoro, dan Endroyono, 2012, Perancangan dan Pembuatan Tahap RF Uplink 145.9 MHz Portable Transceiver Satelit IINUSAT-01, Skripsi, Jurusan Teknik Elektro, ITS, Surabaya

Tahap, P., Wiyah, R. A., \& Hendrantoro, G. (2013). Downlink 2 . $4 \mathrm{GHz}$ Untuk Pengiriman Citra Pada Sistem Komunikasi Satelit Nano. Jurnal Teknik POMITS, 2(1), 160-165.

Utomo, Mardi, 2012, Pemancar FM, Majalah Elektron-TH.XVIII, https://purwanto1987.wordpress.com/2012/07/18/desain-penguat-daya-rf-darimajalah-elektron-itb/, diakses pada tanggal 3 April 2017.

Wedlock, B.D., dan Roberge, J.K., Electronic Components and Measurement, PrenticeHall, Englewood Cliffs, N.J., 1969.

Waluyo, C. B. (2014). Analisa Performansi Dan Coverage Wireless Local Area Network 802.11 B/G/N Pada Pemodelan Sistem E-Learning. Prosiding Seminar Nasional Aplikasi Sains \& Teknologi (SNAST), (November), 69-74.

Waluyo, C. B. (2016). Analisis Mimo Untuk Peningkatan Kapasitas Sistem Seluler 4G Lte Pada Sistem Komunikasi High Altitude. Jurnal Angkasa, VIII(Nomor 2), 111-120.

Waluyo, C. B., \& Iskandar. (2015). Performance analysis for mimo lte on the high altitude platform station. International Conference on Electrical Engineering, Computer Science and Informatics (EECSI), 4(5), 308-313. https://doi.org/10.11591/eecsi.4.1105 